\title{
Nutrients and bioactive potentials of edible green and red seaweed in Korea
}

\author{
K. K. Asanka Sanjeewa, WonWoo Lee and You-Jin Jeon ${ }^{*}$
}

\begin{abstract}
Background: Traditionally, East-Asians (Korea, Japan, and China) utilize seaweeds as a food source and ingredient in traditional medicine. Korea is one of the biggest seaweed producer and consumer in the global trade. Especially, side dishes made from seaweeds are very popular in the traditional Korean cuisines. Seaweeds are popular as fresh vegetable salads and soup or eaten as snacks.

Main body: Seaweeds are rich in essential nutrients, minerals, and vitamins as well as a promising source of novel bioactive compounds. The compounds (polysaccharides, polyphenols, and sterols) present in the edible Korean seaweeds possess important bioactive properties such as antioxidant, anti-inflammation, anticancer, anti-diabetic, and anticoagulant properties. Thus, the long-term consumption of seaweed has a potential to reduce the risk of cancer, diabetes, obesity, and inflammation-related complications. However, seaweed consumption is limited to the small population around the globe. Thus, it is important to increase the awareness of the health benefits of seaweeds consumption among the general population.
\end{abstract}

Short conclusion: In the present study, we discussed some popular green and red edible Korean seaweeds and their health-promoting properties. This study might be useful to increase the public awareness of the consumption of seaweed as a food source.

Keywords: Edible seaweed, Bioactive, Functional foods

\section{Background}

Seaweeds have been used as human food since ancient times. The use of seaweeds as a food traced back to the fourth century in Japan and sixth century in China. Especially, those people who lived near the coastal area preferred to consume seaweeds as a main or side dish, or as a soup (Kllinc et al. 2013). Usually, Europeans consume less amount of seaweeds compared to the Asians due to the regulations and the food habits of Europeans. However, during the last few decades, consumption of seaweed in European countries gradually increased with the identification of invaluable health effects associated with seaweeds (Mabeau and Fleurence 1993). In addition to the nutritious value, seaweeds are a rich source of structurally diverse bioactive components such as phlorotannins, sulfated polysaccharides, and pigments. Each and every year, thousands of scientific reports are published about the bioactive properties and the potential health benefits associated with the edible seaweeds. As a result of this

\footnotetext{
* Correspondence: youjinj@jejunu.ac.kr

Department of Marine Life Sciences, School of Marine Biomedical Sciences, Jeju National University, Jeju 63243, Republic of Korea
}

public awareness, demand for seaweeds and their commercial products slightly increased in the global trade (Sanjeewa et al. 2017).

Korea is one of the important edible seaweed producers in the global market. Harvesting from the wild and cultivation (mariculture, land-based culture, and farming) are the major seaweed production methods. According to the FAO databases, in 2014, Korea alone commercially cultivated around 397,841 tons of Porphyra spp., 283,707 tons of sea mustard, 6055 tons of green laver, and 16,563 tons of other brown seaweed species (FAO 2014). Korean people usually consume seaweeds in fresh forms or dry them under the sun to make different food items and to keep a long time. In the traditional Korean cuisines, seaweeds are popular as soup (mi-yeok-guk and mom-guk), snacks (kimbugak), vegetable, pickle, and salad or used to prepare gim-bap. Gim-bap is a mixture of gim (dried seaweed) and steamed white rice, which contains a mixture of vegetables and meat types. Gim-bap is a popular food item in Korea as a side dish and simple lunch. Most of the Korean people usually consume dried and fresh gim as their side dish (Kim et al. 
2015a, b, Fleurence and Levine 2016). However, the popularity of seaweeds as processed food items or as functional materials is low in Europe and South Asia. Therefore, in the present section, special attention is given to collect the literature about edible green and red seaweeds present in Korea. In addition, the bioactive properties reported from edible Korean green and red seaweeds are also discussed in the present review.

\section{Main text}

\section{Green seaweeds}

\section{Capsosiphon fulvescens (mae-saeng-i)}

Capsosiphon fulvescens is an edible green seaweed in Korea. C. fulvescens is abundant in the southern coast of Korea as well as throughout the world. Traditionally, $C$. fulvescens is used as an ingredient in functional foods for centuries in Korea (Sharma and Rhyu 2014). Specifically, these seaweeds are used to treat stomach disorders and hangovers (Go et al. 2011). In general, mae-saeng-i contains around $55 \%$ polysaccharides, $30 \%$ proteins, $13 \%$ ash, and $1 \%$ lipids from its dry weight. In addition, mae-saeng-i is a good source of essential macro and micro minerals such as $\mathrm{Fe}, \mathrm{Se}, \mathrm{Ca}, \mathrm{Mg}, \mathrm{Na}, \mathrm{K}$, and P. Specifically, mae-saeng-i contains large amounts of $\mathrm{Fe}$ and Se compared to the other edible green seaweeds. In addition, polysaccharides presented in C. fulvescens build up with fructose, galactose, glucose, maltose, and sucrose (Park 2005, Yang et al. 2005). C. fulvescens is a popular side dish in Korean cuisines due to the unique flavor and soft texture as well as its healthenhancing properties, such as anticoagulant, anticancer, anti-inflammatory, and immuno-modulatory properties (Hwang et al. 2008; Kim et al., 2013b, c). Boiling C. fulvescens with oysters to prepare soup and/or steaming $C$. fulvescens with rice to prepare gul-guk-bap are two popular food items prepared from mae-saeng-i. In addition to the fresh seaweed, powdered C. fulvescens is also popular in Korean local markets due to the diverse food applications of mae-saeng-i powder such as soup and juice porridge.

\section{Caulerpa lentillifera (ba-da-po-do)}

Caulerpa lentillifera is a green seaweed which is naturally distributed in the tropical regions. C. lentillifera is commercially cultivated in East-Asian countries to be utilized as food for farm animals and humans (Kim KO 2015). In addition to the food applications, C. lentillifera is used to treat wastewater accumulate in shrimp farms (Apiratikul et al. 2011). C. lentillifera is usually consumed as a fresh salad or as a salt-preserved form in Korea, Japan, and the Philippines. According to the previous studies, the dried biomass of C. lentillifera contains around 10\% protein, 16 . $76 \%$ polyunsaturated fatty acids, $1 \%$ lipids, $38.6 \%$ carbohydrates, and $37 \%$ ash from its dry weight. Moreover, C. lentillifera is rich in essential minerals $(\mathrm{Na}, \mathrm{K}, \mathrm{Ca}$, and $\mathrm{Mg}$ ), omega-3 fatty acids, dietary fibers, and vitamins (A and C)
(Matanjun et al. 2009, Sharma and Rhyu 2014). Traditionally, C. lentillifera extracts are used to treat high blood pressure, rheumatism, and diabetes, as well as to treat bacterial and fungal infections (Sharma et al. 2015). Recently, a number of studies demonstrated that $C$. lentillifera extracts have a potential to develop as a drug or functional material to treat cancers and diabetes mellitus (Nguyen et al. 2011; Sharma and Rhyu 2014).

\section{Enteromorpha linza (ip-parae)}

Enteromorpha linza is a broad paddle-shaped green seaweed commonly seen in the coasts of Korea and Japan as well as in European and Mediterranean coastal areas. E. linza prefers to grow on rocky surfaces and rapidly colonizes on the bare surfaces, and it also can grow on compacted mud banks or even sandy shores (Cho et al., 2011b, b; Patra and Baek 2016). E. linza has long been used as a food source in traditional Korean cuisines, which is used to prepare soup and seasoned cooked vegetables or consume after mixing with vegetables and spices. Recently, Patra and Baek (2016) reported the essential oil presented in E. linza has a potential to inhabit the foodborne pathogens (Bacillus cereus and Staphylococcus aureus). In addition to antimicrobial properties, polysaccharides separated from E. linza are found to possess interesting bioactive properties such as blood lipid reduction and anti-inflammatory, antioxidant, and anticancer properties (Zhang et al. 2011).

\section{Enteromorpha prolifera (gasi-parae)}

E. prolifera is an abundant fouling green seaweed in Asian countries such as Korea, China, and Japan, which prefers to grow from the intertidal to the upper subtidal zones (Cho et al., 2011b, b). Traditionally, Korean people use gasi-parae to prepare salads or preserve as a soup after boiling in hot water. In addition, E. prolifera is used as an ingredient in meals and cookies or as essences (Aguilera-Morales and Casas-Valdez, 2005). The southern coast of Korea is a popular region for commercial cultivation of the Enteromorpha species (Huh et al. 2004). E. prolifera is a rich source of essential nutrients; the dried gasi-parae contains around 9 14\% protein and $32 \sim 36 \%$ ash. In addition, it contains $\mathrm{n}-3$ and $\mathrm{n}-6$ fatty acids, 10.4 and $10.9 \mathrm{~g} / 100 \mathrm{~g}$ of total fatty acids, respectively (Aguilera-Morales and Casas-Valdez, 2005). The studies carried out with extracts and compounds collected from E. prolifera which was found to possess a range of bioactive properties such as antioxidant, blood lipid reduction, anticancer, immune modulatory, and anti-inflammatory properties (Shi et al. 2017).

\section{Ulva pertusa (goo-meong-gal-parae)}

Ulva pertusa is a common edible seaweed distributed in the coastal waters (mid-littoral to shallow sublittoral 
zone) of Korea, China, and Japan (Song et al. 2010). In general, the production rate of $U$. pertusa was reported as $7 \mathrm{~kg} / \mathrm{m}^{2}$ (wet weight) (Kwon et al. 2017). In addition to the high growth rate and bioavailability, $U$. pertusa is rich in vitamins, trace elements, and dietary fibers and is also considered as a low-calorie food. Moreover, $U$. pertusa has been used as an ingredient in the traditional medicine for urinary diseases, sunstroke, and hyperlipidemia (Qi et al. 2006), in addition to the food value, which is useful to reduce eutrophication in mariculture waters and increase the survival rate productivity and feeding efficiency of the cultured shellfish species, such as shrimps and prawns (Jin and Dong 2003).

\section{Codium fragile (cheong-gak)}

Codium fragile is an edible green seaweed of family Codiaceae. C. fragile is abundant on the coasts of Korea, China, Japan, and some coastal areas of Northern Europe. Traditionally, Korean people use $C$. fragile as a food ingredient which has been used in traditional medicine to treat dysuria, dropsy, and enterobiasis. Other than the food and traditional medicinal applications, secondary metabolites present in C. fragile are found to possess interesting bioactive properties such as antioxidant, anticancer, anti-angiogenic, and anti-inflammatory properties (Lee et al. 2017).

\section{Red seaweeds}

The main application of red seaweed is as a source of hydrocolloids. Agar and carrageenans are two wellknown hydrocolloids separated from red seaweed which are used in diverse medicinal and food applications. Thus, the demand for hydrocolloid-based industries has been expanding rapidly during the past few decades (Meinita et al. 2017). In addition to the commercial applications, traditionally, Korean people consume some red seaweed species in fresh forms and after processing them into different types of foods such as soup, cookies, or snacks.

\section{Porphyra spp. (gim)}

Laver is one of the popular edible red seaweed among the people living in countries like Korea, China, and Japan (Lee et al., 2016a, b). Modern commercial cultivation of laver species arose during the 1960s with the identification of the Conchocelis phase of Porphyra, which allowed artificial seeding and maximizing production in the artificial environmental conditions (Shaw and Liu 2000). Gim is rich in proteins, vitamins (A, B, and $\mathrm{C}$ ), and minerals (iron, zinc, copper, manganese, and selenium) as well as contains a low amount of simple sugars compared to the other edible seaweeds (Shaw and Liu 2000, Fleurence and Levine 2016). Porphyra tenera and $P$. yezoensis are commonly used to produce commercial food products such as dried seasoned laver and roasted laver for sushi (Park et al. 2014). The dried and roasted laver are popular food products in the Korean food market as well as in the international market due to the high nutritional value, texture, compactness, and pleasant taste of processed Porphyra spp. (Park et al. 2014; Cho et al. 2015). Usually, mlavers are consumed as dried seaweed. Kim-bu-gak (snack) and gim-bap are popular food products in the Korean food market produced from laver (Oh and Choi 2015).

\section{Gelidium amansii (wu-mu-ga-sa-ri)}

Gelidium amansii is a popular edible red seaweed, which is commonly used as a food ingredient in Korea, Taiwan, China, and Japan. Specifically, agar jelly made from hot-water extracts of $G$. amansii is a popular food item in Taiwan and Japan (Yang et al. 2017). This red seaweed is a rich source of carbohydrates, especially galactose $(23 \%)$ and glucose $(20 \%)$ (Wi et al. 2009). G. amansii is considered as a cheap source of agar. Thus, this red seaweed is commonly cultivated for agar production (Kang et al. 2013). Previous studies carried out with $G$. amansii demonstrated the supplementation with G. amansii in high-cholesterol and high-fat diets has a potential to reduce liver and plasma lipid levels in diabetic rats (Yang et al. 2017).

\section{Gracilaria verrucosa (go-si-rae-gi)}

Gracilaria verrucosa is a popular edible red seaweed in Korea. G. verrucosa is commercially cultivated in Asian countries to obtain food-grade agar for different industrial applications. In addition to the agar production, $G$. verrucosa is a popular raw material in the bio-ethanol industry due to its high level of ethanol extraction efficiency. Galactose and glucose are the principal monosaccharide types obtained from G. verrucosa for bio-ethanol production (Meinita et al. 2017; Nguyen et al. 2017). In addition to the food applications, a number of studies reported the secondary metabolites presented in G. verrucosa have a potential to develop as functional materials (Dang et al. 2008).

\section{Gracilariopsis chorda (gae-ko-silaegi)}

Gracilariopsis chorda is a perennial red seaweed, which is popular for its wide medicinal benefits and which is also utilized as a food ingredient in Korea (Mohibbullah et al. 2016). In addition to Korea, G. chorda is utilized as a raw material for produce agar in France, Indonesia, Mexico, Morocco, Portugal, and Spain. Usually, G. chorda biomass contains large amounts of carbohydrate $\left[34.4 \%\left(\mathrm{~g} \mathrm{~g}^{-1}\right.\right.$ DW)]. In contrast to the food value of G. chorda, a number of studies reported G. chorda is a potential candidate for bioethanol production due to its high growth rate and bio-availability (Meinita et al. 2013). 


\section{Gloiopeltis tenax (pul-ga-sa-ri)}

Gloiopeltis tenax is an important red seaweed which belongs to the phylum Rhodophyta and the class Florideophyeeae. G. tenax is an economically important edible red seaweed which has been traditionally used as food and as a sizing material in the silk industry (Chen et al. 2011; Zheng et al. 2012). In addition to the food applications, G. tenax is traditionally used in the treatment of diarrhea and colitis (Zheng et al. 2012).

\section{Bioactive effects reported from green and red seaweeds}

\section{Antioxidant properties}

Free radicals are produced during the metabolism as a result of the mitochondrial metabolism, inflammatory responses, phagocytosis, and physical exercises. The production of free radicals accelerates with the external factors such as smoking, radiation, drugs, and pesticides (Carocho and Ferreira 2013). Continuous overproduction of free radicals in biological systems is capable of damaging all classes of chemicals (proteins, amino acids, nucleic acids, and carbohydrates) in the biological materials. Thus, it is important to avoid oxidative stress in the biological systems to protect organisms from oxidative damage (Kang et al., 2015b). According to the previous reports, green and red seaweed used in traditional Korean cuisines are found to possess interesting antioxidant properties. Herein, we discussed some antioxidant properties reported from edible red and green seaweed used in traditional Korean dishes.

Kim et al. (2015a) attempted to study the antioxidant activity of a protein purified from C. fulvescens. According to the authors, the $33-\mathrm{kDa}$-weight protein had better radical scavenging activity against hydroxyl radical, 2,2-diphenyl-1picrylhydrazyl radical (DPPH), hydrogen peroxide $\left(\mathrm{H}_{2} \mathrm{O}_{2}\right)$, and superoxide anion. In addition, the authors found that the isolated protein has a potential to inhibit the $\mathrm{H}_{2} \mathrm{O}_{2}$-mediated ROS production in HepG2 cells at concentration of $0.01 \sim 10 \mu \mathrm{g} / \mathrm{mL}$. Cho et al. (2011a) studied the antioxidant properties of extract and fractions separated from E. prolifera. In this study, the authors reported that the ethanol extract of E. prolifera had profound DPPH and hydroxyl radical scavenging activity as well as reducing power compared to the commercial antioxidants such as BHA and $\alpha$ tocopherol. In addition, the authors reported that, the antioxidant effects of E. prolifera extracts and fractions had correlation with total phenolic contents in each extract. Nguyen et al. (2011) also attempted to evaluate the DPPH, $\mathrm{H}_{2} \mathrm{O}_{2}$, and ferrous ion chelating capacity of ethanolic extracts separated from dry $C$. lentillifera using two drying methods including thermal drying and freeze-drying. According to the authors, freeze-dried seaweed had better antioxidant capacity $(0 \sim 100 \mathrm{ppm})$ as well as high total phenolic contents compared to the thermal drying method. Kim (2010) studied the total phenolic contents and antioxidant activities of $U$. pinnatifida and $C$. fulvescens under different drying conditions. According to the results, radical scavenging activity and phlorotannin contents were higher in the extracts separated by the vacuum drying method compared to the hot air drying method. According to the results, the antioxidant properties of seaweeds might depend on the processing method. Zheng et al. (2012) evaluated antioxidant properties of extract separated from $G$. tenaxi using the supercritical carbon dioxide fluid extraction technique. According to the results, the extract had strong DPPH, lipid peroxidation inhibition capacity, and hydroxyl radical-scavenging activity compared to the commercial antioxidant butylated hydroxytoluene (BHT). Seo et al. (2012) attempted to evaluate the effect of $G$. amansii on lipid accumulation and ROS production in 3T3-L1 cells. In this study, the authors found that $80 \%$ methanolic extract of G. amansii $(1 \sim 100 \mu \mathrm{g} / \mathrm{mL})$ has a potential to downregulate the ROS production of 3T3-L1 preadipocytes by reducing mRNA levels of a nicotinamide adenine dinucleotide phosphate hydrogen oxidase 4 and upregulating the expression levels of anti-oxidant proteins such as superoxide dismutases, glutathione peroxidase, and glutathione reductase. Mohibbullah et al. (2015) studied the neuroprotective effect of ethanol extract from G. chorda using hypoxia/reoxygenation-induced oxidative stress in cultured hippocampal neurons. According to the results, out of 23 seaweeds examined, G. chorda had the best neuroprotection at $15 \mu \mathrm{g} / \mathrm{mL}$, followed by $U$. pinnatifida. In addition, the authors suggested that the active compound in G. chorda is arachidonic acid, which is responsible for neuroprotection against hypoxia/reoxygenation-induced oxidative stress.

In addition to the crude organic solvent extracts, Zhang et al. (2013b) studied antioxidant properties of water-soluble and alkali-soluble polysaccharides separated from E. linza. According to the authors, the superoxide radical scavenging effect of two polysaccharides was ranged between 10.4 and $15.6 \mu \mathrm{g} / \mathrm{mL}\left(E_{50}\right)$. In addition to these significant findings, Wang et al. (2013a) reported that the low-molecular-weight polysaccharides separated from E. linza have potential radical scavenging properties against superoxide and hydroxyl radicals. Zhang et al. (2014) also reported that a low-molecular-weight polysaccharide isolated from E. linza has a potential to be used as an ingredient in food and pharmaceutical industries due to its strong superoxide $\left(\mathrm{EC}_{50}=5.44 \mu \mathrm{g} / \mathrm{mL}\right)$ and hydroxyl radical $\left(\mathrm{EC}_{50}=920 \mathrm{ng} / \mathrm{mL}\right)$ scavenging properties. Xu et al. (2015) reported that a $45.4-\mathrm{kDa}$ polysaccharide purified from $E$. prolifera has better radical scavenging properties such as DPPH, hydroxyl, and superoxide anion radicals. Qi and Sun (2015) attempted to 
evaluate the antioxidant properties of a polysaccharide collected from $U$. pertusa in the liver of hyperlipidemic rats. According to the results, doses of 125 and $250 \mathrm{mg} / \mathrm{kg}$ had better superoxide dismutase activity as well as glutathione peroxidase than the hyperlipidemic rats. Recently, Kim et al. (2017) reported the crude protein separated from $C$. fulvescens has a potential to protect hippocampal neurons against ethanol-induced oxidative stress in Sprague-Dawley rats (male/250 300 g) by upregulating the mature brain-derived neurotrophic factor as well as protecting against chronic ethanol-exposed endoplasmic reticulum (ER) stress in rats (10 20 mg/kg). Recently, Lee et al. (2017) reported that polysaccharides separated from $P$. yezoensis by microwave-assisted rapid enzyme digest system have a potential to be developed as functional material due to its strong antioxidant properties. According to the results, low-molecular-weight polysaccharide is found to possess strong alkyl radical scavenging activity with $\mathrm{IC}_{50}$ of $114.4 \mu \mathrm{g} / \mathrm{mL}$.

\section{Anticancer properties}

Cancer is a major health care problem in many parts of the world and was reported to cause 8.8 million deaths in 2015. According to the previous studies, metabolites present in seaweed are capable of suppressing the cancer cells and the further development of cancer (Kim et al. 2013a, b, c). Thus, promotion of seaweed consumption might be a possible approach to reduce cancer risk (Sanjeewa et al. 2017). In this section, we discussed some outcomes of anticancer studies carried out with green and red Korean edible seaweeds.

Cho et al. (1997) attempted to evaluate anticancer and anti-mutagenic properties of the nine Korean seaweeds (sea lettuce, sea tangle, chlorella, sea mustard, sporophyll of sea mustard, seaweed papulosa, fusiforme, purple laver, and Ceylon moss) using 20\% methanolic extracts on human colon cancer (HT-29) cells and Salmonella typhimurium TA100 cells. According to the authors, all seaweed extracts had promising anti-mutagenic activity against aflatoxin $\mathrm{B}_{1}$ and N-methyl-N'-nitro-N-nitrosoguanidine in S. typhimurium TA100. In addition, sporophyll of sea mustard, sea tangle, and sea mustard extracts had anticancer activity on AGS human gastric adenocarcinoma cells and HT-29 human colon carcinoma cells at the $0.2 \mathrm{mg} / \mathrm{mL}$ concentration. Maeda et al. (2012b) attempted to study anticancer effects of $\beta-1,3$-xylooligosaccharide prepared from $C$. lentillifera on human breast cancer (MCF-7) cells. In this study, the authors found that 1,3-xylooligosaccharides have a potential to inhibit the proliferation of MCF-7 cells via inducing condensation of chromatin and altering the apoptosis protein expression levels in 1,3-xylooligosaccharide-exposed MCF-7 cells (downregulated expression of PARP and upregulated expression of caspase-3/7). The Wnt signals are usually associated with the development of organs, cell proliferation, morphology, and motility within vertebrates. However, unusual activation of Wnt proteins in cancer cells is responsible for the upregulated proliferation and survival rates associated with cancer cells. Therefore, inhibition or downregulation of Wnt signal-associated proteins is considered as a key approach in anticancer drugs (Kim et al. 2013b). Kim et al. (2013b) attempted to evaluate anticancer properties of glycoprotein isolated from C. fulvescens. According to the authors, glycoprotein inhibited the upregulated expressions of Wnt-1 signal-associated proteins as well as cell cyclerelated proteins Cyclin D and cell cycle progress in gastric cancer cells $(5 \sim 20 \mu \mathrm{g} / \mathrm{mL})$. Deregulated levels of apoptosis in cancer cells are considered as a major barrier to effective elimination of cancer cells. Thus, the compounds that have a potential to restore apoptosis have a great potential to develop as anticancer drugs (Sanjeewa et al. 2017). Choi et al. (2014) attempted to evaluate the anticancer properties of methyl alcohol extract separated from E. linza on human leukemia cells (U937). In this study, the authors demonstrated the extract has a potential to induce apoptosis in U937 cell via upregulated expression of death receptors 4 and 5 and downregulated expression of antiapoptotic proteins such as Bcl-2 and Bcl-xL and IAP family proteins $(50 \sim 300 \mu \mathrm{g} / \mathrm{mL})$. In addition, Kwon and Nam (2007) reported a polysaccharide isolated from C. fulvescens has a potential to inhibit the proliferation and cell cycle progression of gastric cancer cells via upregulating caspase- 3 activation and downregulating Bcl-2 expression in polysaccharide-exposed cancer cells. Recently, Kim et al. (2015b) studied the anticancer properties of ethanol extracts of P. tenera on oral cancer cells (YD-10B). According to the results, exposure of YD-10B cells to the $P$. tenera extracts $(50-200 \mu \mathrm{g} / \mathrm{mL})$ for 24 or $48 \mathrm{~h}$ induces the apoptosis cell death in YD-10B cells via upregulating cytochrome $c$ and downregulating the expression levels of procaspase $3 / 9$ and Bcl-2 proteins in YD-10B cells. In addition to these significant results, Zhang et al. (2016) studied the anti-mutagenic effects of polysaccharides separated from E. linza on Allium sativum root cells induced by ultraviolet and sulfur dioxide. According to the results, E. linza polysaccharides had antigenotoxic and antimutagenic activity on A. sativum root cells. However, since A. sativum is a higher plant, it is important to carry out future studies with human or mammal cells in order to develop drugs or functional materials from these polysaccharides.

\section{Anti-inflammation and immunomodulatory properties}

Inflammation is a protective response, which plays an important role in host defense mechanisms. Inflammatory responses are useful to stimulate tissue regeneration and defeat pathogens (Pesic and Greten 2016), while uncontrolled and continuous inflammatory responses are linked 
to tissue destruction, carcinogenesis, obesity, and obesityassociated insulin resistance (Kundu and Surh 2008, Jais and Bruning 2017). Thus, compounds with inhibitory effects on inflammatory mediators have a potential to develop as functional materials or drugs to treat inflammation-associated diseases. In this section, we discussed anti-inflammatory properties reported from some Korean edible seaweeds.

Recently, Ali et al. (2016) reported 3-hydroxy-4,7megastigmadien-9-one isolated from $U$. pertusa has a potential to inhibit lipopolysaccharide (LPS)-induced inflammatory responses in bone marrow-derived dendritic cells via inhibiting NF- $\mathrm{KB}$ and MAPK-associated proteins. According to the results, the isolated compound had strong inhibition effect on pro-inflammatory mediators such as interleukin (IL)-12 p40 $\left(\mathrm{IC}_{50}=7.85 \pm 0\right.$. $32 \mu \mathrm{M})$ and IL-6 cytokine $\left(\mathrm{IC}_{50}=7.86 \pm 0.18 \mu \mathrm{M}\right)$ but not TNF- $\alpha$. However, in an another study, Ali et al. (2017) reported that 3-hydroxy-4,7-megastigmadien-9one isolated from $U$. pertusa has considerably high TNF$\alpha$ inhibition effect on LPS-induced bone marrow-derived dendritic cells $\left(\mathrm{IC}_{50}=7.56 \pm 0.21 \mu \mathrm{M}\right)$. In addition, the authors reported that the inhibition of the transcriptional activity of AP-1 and NF- $\mathrm{kB}$ is also responsible for inhibiting LPS-induced inflammation in dendritic cells. Manzoor et al. (2016) attempted to study the inhibitory effect of 4-hydroxy-2,3-dimethyl-2-nonen-4-olide isolated from $U$. pertusa in CpG-stimulated bone marrowderived dendritic cells. According to the results, CpG DNA-stimulated bone marrow-derived dendritic cells had strong inhibition of interleukin (IL)-12 p40 and IL-6 production with $\mathrm{IC}_{50}$ values ranging from $7.57 \pm 0.2 \sim 10$. $83 \pm 0.3 \mu \mathrm{M}$ respectively. Recently, Lee et al. (2017) attempted to evaluate anti-inflammatory properties of hot water extract separated from C. fragile on LPS-stimulated RAW264.7 cells and carrageenan-induced male SpragueDawley rats (300 330 g, 10 weeks old). According to the results, $C$. fragile extracts inhibited LPS-induced inflammatory responses in macrophage cells at the concentrations ranging between 50 and $200 \mu \mathrm{g} / \mathrm{mL}$. In addition, oral administration of seaweed extract (50 200 mg/kg body weight) suppressed carrageenan-induced paw edema thickness $(6 \sim 50 \%)$ in rat model.

In addition to the anti-inflammatory properties, some studies reported that the extracts separated from Korean edible green and red seaweed have a potential to act as immunomodulatory agents. In this subchapter, immunomodulatory properties reported from Korean edible seaweeds are briefly introduced. Karnjanapratum et al. (2012) attempted to evaluate the immunomodulatory properties of sulfated polysaccharides isolated from $C$. fulvescens using in vitro RAW 264.7 cells. According to the results, exposure of C. fulvescens polysaccharides to RAW 264.7 cells triggers the production of $\mathrm{NO}, \mathrm{PGE}_{2}$, and cytokines significantly compared to the control treatment (6. $25 \sim 25 \mu \mathrm{g} / \mathrm{mL}$ ). Maeda et al. (2012a) also reported the purified sulfated polysaccharide obtained from C. lentillifera has a potential to act as an immunomodulatory agent. According to the authors, the isolated polysaccharide increased the NO production from RAW 264.7 cells via upregulated activation of NF- $\mathrm{kB}$ and MAPK-associated inflammatory proteins at the concentration of $1 \sim 4 \mu \mathrm{g} / \mathrm{mL}$.

\section{Anti-diabetic and anti-obesity properties}

Diabetes is one of the most prevalent and chronic metabolic diseases, which alerts the glucose metabolism with abnormally high plasma glucose levels (Leung et al. 2017). Obesity is a metabolic disorder which can define as increased body weight caused by excessive fat accumulation. Obesity presents a risk to health with an increase in health care problems and reduced life expectancy by inducing the risk for the pathogenesis of other chronic disease conditions such as diabetes and cardiovascular and renal diseases (Lee et al., 2016a; Leung et al. 2017). Recently, the studies carried out with Korean edible seaweeds have demonstrated the metabolites present in those seaweeds contain promising anti-diabetic and anti-obesity properties. In the present section, we discussed some anti-diabetic and anti-obesity properties reported from Korean edible seaweeds.

Previously, Zhang et al. (2013a) compared the $\alpha$ glucosidase inhibitory effects of five polysaccharide fractions purified from E. linza along with acarbose, commercial $\alpha$-glucosidase inhibitor. According to the results, purified polysaccharides inhibited the $\alpha$ glucosidase with $\mathrm{IC}_{50} 0.38 \sim 0.58 \mathrm{mg} / \mathrm{mL}$. However, in the same study, the authors found that $\mathrm{IC}_{50}$ of acarbose on $\alpha$-glucosidase was $0.46 \mathrm{mg} / \mathrm{mL}$. Sharma and Rhyu (2014) reported the extract separated from $C$. lentillifera has a potential to increase the insulin secretion from rat insulinoma cells and stimulate the glucose uptake in 3T3-L1 adipocytes. In addition, the authors reported that $C$. lentillifera $(5 \sim 25 \mu \mathrm{g} / \mathrm{mL})$ extract preserved functional $\beta$-cell mass from cytokine-induced injury and downregulated the inflammatory response by inhibiting $\mathrm{NO}$ and iNOS production from cytokine-exposed cells. Woo et al. (2013) reported that $80 \%$ ethanolic extract separated from G. verrucosa has a potential to increase glucose uptake in 3T3-L1 adipocytes without showing any cytotoxic effect on 3T3-L1 adipocytes. Moreover, the authors suggest that AMPK signal pathway might be responsible for the anti-adipogenic and anti-diabetic effects of G. verrucosa extract in 3T3-L1cells.

Malfunctions of the AMPK and PI3K/AKT associated signal pathways in insulin-sensitive tissues have been identified as one major cause for accumulation of blood 
glucose level. Recently, Sharma et al. (2015) attempted to evaluate the effects of $70 \%$ ethanolic extract separated from C. lentillifera (CLE) on AMPK- and PI3K/AKT-associated protein expression levels in $\mathrm{C} 57 \mathrm{BL} / \mathrm{KsJ}-\mathrm{db} / \mathrm{db}$ mice. According to the result, CLE (250 and $500 \mathrm{mg} / \mathrm{kg}$ ) upregulated the glucose uptake of $\mathrm{db} / \mathrm{db}$ mice via stimulating the PI3K/AKT signaling pathway without altering the mice weight or dietary intake. Han et al. (2016) also reported that whole wheat bread prepared using $C$. fulvescens has a potential to reduce the plasma glucose and lipid levels in Sprague-Dawley rats. Recently, Kang et al. (2016) evaluated the in vitro and in vivo anti-diabetic effect of $70 \%$ ethanol extract from G. amansii (GAE). According to the authors, under in vitro conditions, GAE suppressed differentiation of 3T3-L1 adipocyte through downregulation of adipogenesis and lipogenesis. In addition to this significant finding, in vivo results suggest that GAE has a potential to decrease the body weight gain and adipose cell size in high-fat diet-induced obesity in mice. Tang et al. (2013) reported that a partially purified polysaccharide separated from E. prolifera has a potential to reduce blood lipid and oxidative stress in high-fat diet-induced mice fed high-fat diet. According to the authors, oral administration of separated polysaccharide $(300 \mathrm{mg} /$ $\mathrm{kg}$ body weight) significantly increased the activities of endogenous antioxidant enzymes such as superoxide dismutase, glutathione peroxidase, and catalase.

\section{Antimicrobial properties}

In the food processing and other food-related industries, special attention is given to avoid microbial infections. Thus, food poisoning, food spoilage, and other foodrelated infections have become an important topic of concern in the food processing and other food-related industries. To avoid food contaminations and increase the shelf life, a large number of synthetic food preservatives has been developed. However, market demand for food products with synthetic food preservatives and antimicrobial agents continuously get reduced due to the adverse side effects associated with those food preservatives (Patra and Baek 2016). During the last few decades, a number of food preservatives developed from the natural origins. The present section briefly discussed about antimicrobial activities reported from Korean edible seaweeds.

Recently, Shao et al. (2017) reported that polysaccharides obtained from $E$. prolifera have a potential to act as an antimicrobial compound against Bacillus subtilis, Escherichia coli, Pseudomonas aeruginosa, Staphylococcus aureus, and Salmonella spp. According to the results, the inhibition zone diameters were ranged between 8.90 and $14 \mathrm{~mm}(200 \mu \mathrm{L}$ of $16 \mathrm{mg} / \mathrm{mL}$ drop$)$. In addition, the authors reported that minimum inhibition concentration of tested polysaccharides were ranged between 1 and
$4 \mathrm{mg} / \mathrm{mL}$ against aforementioned bacterial strains. Patra et al. (2015) attempted to evaluate the antibacterial properties of an essential oil separated from E. linza against E. coli and S. typhimurium. In this study, the authors found that the minimum inhibitory effect of isolated oils against Escherichia coli and S. typhimurium was 12.5 and $25 \mathrm{mg} / \mathrm{mL}$, respectively (Patra et al. 2015). Patra and Baek (2016) studied the inhibitory effects of foodborne pathogens using the essential oil from E. linza. According to the authors, the extracted oils have a potential to inhibit growth of Bacillus cereus (12.3-12.7 mm inhibition zone) and S. aureus (12.7-13.3 mm inhibition zone), two important foodborne pathogens. Prevotella intermedia and Porphyromonas gingivalis are two gram-negative periodontal pathogens responsible for pathogenesis of periodontitis in a chronic inflammatory disease. Park et al. (2013) attempted to study the antimicrobial activities of stearidonic and gamma-linolenic acids separated from $E$. linza against aforementioned bacterial pathogens. According to the results, minimal inhibitory concentration values of stearidonic and gamma-linolenic acids were 39 . $06 \mu \mathrm{g} / \mathrm{mL}$ against $P$. intermedia and $9.76 \mu \mathrm{g} / \mathrm{mL}$ against $P$. gingivalis. In addition, Zheng et al. (2012) reported that the extracts collected from G. tenax have moderate inhibitory effects on foodborne pathogens such as S. aureus, Enterococcus faecalis, Pseudomonas aeruginosa, and Escherichia coli. According to the results, minimum inhibitory concentration of extracts ranged between $3.9 \mathrm{mg} /$ and $15.6 \mathrm{mg} / \mathrm{mL}$ under tested conditions against aforementioned bacterial species.

\section{Anticoagulant properties}

Heparin is a sulfated polysaccharide, which has been identified as a strong anticoagulant compound. Heparin is used as a commercial anticoagulant drug for the treatment and prevention of thromboembolic diseases for more than seven decades (Jin et al. 1997; Walenga and Bick 1998; Pushpamali et al. 2008). However, due to the adverse side effects associated with heparin (alopecia, allergic reactions, thrombocytopenia, eosinophilia, heparin-induced thrombocytopenia, heparin-associated osteoporosis, and skin reactions), requirement for some effective alternatives for heparin increased (Walenga and Bick 1998). In this section, we briefly discussed about potentials of secondary metabolites present in Korean edible seaweeds to develop as anticoagulant agents.

Qi et al. (2013) reported that two water-soluble sulfated polysaccharides separated from E. linza have a potential to prolong the activated partial thromboplastin time (APTT) and thrombin time (TT) in human plasma. In addition, Wang et al. (2013b) studied the anticoagulant properties of low-molecular-weight polysaccharide prepared from E. linza. According to the authors, anticoagulant activities of all the samples were increased 
with the degree of sulfation and had considerable good anticoagulant activity compared to the heparin, a commercial anticoagulant. Synytsya et al. (2015) attempted to evaluate the anticoagulant activity of a sulfated polysaccharide separated from $C$. fulvescens. The authors reported that the polysaccharide (4-linked l-rhamnose-3sulphate and $d$-xylose residues carrying monomeric $d$ glucuronic acid or d-glucuronic acid-3-sulphate on O-2 of some l-rhamnose-3-sulphate units as the side chains) has potential anticoagulant properties. According to the authors, the isolated polysaccharide had significant in vitro anticoagulant activities under tested conditions. Moreover, the isolated polysaccharide significantly prolonged the APTT and TT at the concentrations between
0.01 and $0.2 \mathrm{mg} / \mathrm{mL}$. Kang et al. (2015a) studied the anticoagulant properties of ulvease, a new fibrinolytic protease, separated from $U$. pertusa. According to the results, ulvease possesses direct-acting fibrinolytic and plasminogen-activating activities which have a potential to act on fibrin clot more efficiently than plasmin and/or u-PA. Specifically in this study, the authors found that ulvease hydrolyzed the $A \alpha$ - and $B \beta$-chains of fibrinogen, but ulvease does not hydrolyze the $\gamma$-chain of fibrinogen.

\section{Conclusions}

As a source of food and medicine, seaweeds have a long history in Korea. Korea is one of the biggest consumers and producers of edible seaweeds. Traditionally, Korean

Table 1 Edible red and green Korean seaweeds with reference to their reported bioactive compounds and food applications

\begin{tabular}{|c|c|c|c|}
\hline Name & Applications & Bioactive properties & References \\
\hline \multirow{5}{*}{$\begin{array}{l}\text { Capsosiphon } \\
\text { fulvescens }\end{array}$} & \multirow{5}{*}{$\begin{array}{l}\text { Soup, stomach disorders, and } \\
\text { hangovers }\end{array}$} & Antioxidant & Kim, 2010, Kim et al., 2015a, and Kim et al. 2017 \\
\hline & & Anticancer & Kwon and Nam 2007 \\
\hline & & Immunomodulation & Karnjanapratum et al. 2012 \\
\hline & & Anti-diabetic & Han et al. 2016 \\
\hline & & Anticoagulant & Synytsya et al. 2015 \\
\hline \multirow[t]{4}{*}{ Caulerpa lentillifera } & \multirow{4}{*}{$\begin{array}{l}\text { High blood pressure, rheumatism, } \\
\text { diabetes, and bacterial and fungal } \\
\text { infections }\end{array}$} & Antioxidant & Nguyen et al. 2011 \\
\hline & & Anticancer & Maeda et al., 2012b \\
\hline & & Immunomodulation & Maeda et al., 2012a \\
\hline & & Anti-diabetic & Sharma and Rhyu 2014 and Sharma et al. 2015 \\
\hline \multirow[t]{4}{*}{ Enteromorpha linza } & \multirow[t]{4}{*}{ Soup, seasoned cooked vegetables } & Antioxidant & Zhang et al., 2013a and Wang et al., 2013a, b \\
\hline & & Anticancer & Choi et al. 2014 and Zhang et al. 2016 \\
\hline & & Anti-diabetic & Zhang et al., 2013a \\
\hline & & Antimicrobial & Patra et al. 2015 \\
\hline \multirow{3}{*}{$\begin{array}{l}\text { Enteromorpha } \\
\text { prolifera }\end{array}$} & \multirow{3}{*}{$\begin{array}{l}\text { Ingredient in meals and cookies or as } \\
\text { an essence }\end{array}$} & Antioxidant & Xu et al. 2015 \\
\hline & & Anti-diabetic & Tang et al. 2013 \\
\hline & & Antimicrobial & Shao et al. 2017 \\
\hline \multirow[t]{3}{*}{ Ulva pertusa } & \multirow{3}{*}{$\begin{array}{l}\text { Urinary diseases, sunstroke, and } \\
\text { hyperlipidemia }\end{array}$} & Antioxidant & Qi and Sun 2015 \\
\hline & & Anti-inflammatory & Ali et al. 2016, Ali et al. 2017, and Manzoor et al. 2016 \\
\hline & & Anticoagulant & Kang et al., 2015a \\
\hline Codium fragile & $\begin{array}{l}\text { To treat dysuria, dropsy, and } \\
\text { enterobiasis }\end{array}$ & Anti-inflammation & Lee et al. 2017 \\
\hline \multirow[t]{2}{*}{ Porphyra spp. } & \multirow[t]{2}{*}{ Snacks, rice wraps } & Antioxidant & Lee et al., 2016b \\
\hline & & Anticancer & Kim et al., 2015b \\
\hline \multirow[t]{2}{*}{ Gelidium amansii } & \multirow[t]{2}{*}{ Agar jelly } & Antioxidant & Seo et al. 2012 \\
\hline & & Antimicrobial & Kang et al. 2016 \\
\hline \multirow[t]{2}{*}{ Gracilaria verrucosa } & \multirow[t]{2}{*}{ Agar jelly } & Antioxidant & Heo et al. 2006 \\
\hline & & Anti-diabetic & Woo et al. 2013 \\
\hline Gracilariopsis chorda & Agar & Antioxidant & Mohibbullah et al. 2015 \\
\hline Gloiopeltis tenax & Agar, to treat diarrhea and colitis. & $\begin{array}{l}\text { Antioxidant and } \\
\text { Antimicrobial }\end{array}$ & Zheng et al. 2012 Zheng et al. 2012 \\
\hline Grateloupia filicina & $\begin{array}{l}\text { Agar, traditional food in the } \\
\text { Kangwando area of Korea }\end{array}$ & Antioxidant & Athukorala et al. 2003 and Athukorala et al. 2005 \\
\hline
\end{tabular}


people incorporate seaweeds in to their diets as salads, cookies, or soup. The dried seaweeds are used as ingredients in many food applications such as gim-bap, condiments, or snacks to eat together with tea. Besides the food value of Korean edible seaweeds, accumulating evidences suggest that the secondary metabolites present in those edible seaweeds have a potential to develop as functional materials due to their promising bioactive properties (Table 1). Due to the interesting bioactive properties, seaweed-associated products seem to become one of the pioneer profit-earning businesses in the global trade. However, consumption of seaweeds is still not in the satisfactory level specially in European and Asian countries due to less awareness of health benefits associated with edible seaweeds. In this study, we discussed some food application, bioactive properties, and some bioactive compounds reported from green and red edible seaweeds. Therefore, the content of this article might be useful to increase consumption of seaweeds as well as utilization of seaweed materials as functional ingredients.

\section{Abbreviations}

DPPH: 2,2-Diphenyl-1-picrylhydrazyl radical; $\mathrm{H}_{2} \mathrm{O}_{2}$ : Hydrogen peroxide; IL: Interleukin; iNOS: Inducible nitric oxide synthase; LPS: Lipopolysaccharide; MAPK: Mitogen-activated protein kinases; NF-KB: Nuclear factor KB; NO: Nitric oxide; PGE2: Prostaglandins; ROS: Reactive oxygen species

\section{Funding}

This research was supported by the 2017 scientific promotion program funded by Jeju National University.

\section{Authors' contributions}

KKAS and YJJ designed this study and drafted the manuscript. KKAS, LWW, and YJJ conceived and designed the study and also revised the manuscript. All authors read and approved the final manuscript.

\section{Ethics approval and consent to participate}

Not applicable.

\section{Competing interests}

The authors declare that they have no competing interests.

\section{Publisher's Note}

Springer Nature remains neutral with regard to jurisdictional claims in published maps and institutional affiliations.

Received: 29 December 2017 Accepted: 6 April 2018

Published online: 09 July 2018

\section{Reference}

Aguilera-Morales M, Casas-Valdez M, Carrillo-Domínguez S, González-Acosta B, Pérez-Gil F. Chemical composition and microbiological assays of marine algae Enteromorpha spp. as a potential food source. J Food Compost Anal 2005;18:79-88,

Ali I, Manzoor Z, Koh Y-S. 3-Hydroxy-4,7-megastigmadien-9-one, isolated from Ulva pertusa Kjellman, inhibits LPS-induced inflammatory response by downregulating mitogen-activated protein kinase and NF-KB pathways. J Bacteriol Virol. 2016;46:167-72.

Ali I, Manzoor Z, Koo JE, Kim JE, Byeon SH, Yoo ES, Kang HK, Hyun JW, Lee NH, Koh YS. 3-Hydroxy-4,7-megastigmadien-9-one, isolated from Ulva pertusa, attenuates TLR9-mediated inflammatory response by down-regulating mitogen-activated protein kinase and NF-kappaB pathways. Pharm Biol. 2017; 55:435-40.
Apiratikul R, Madacha V, Pavasant P. Kinetic and mass transfer analyses of metal biosorption by Caulerpa lentillifera. Desalination. 2011;278:303-11.

Athukorala Y, Lee KW, Park EJ, Heo MS, Yeo IK, Lee YD, Jeon YJ. Reduction of lipid peroxidation and $\mathrm{H}_{2} \mathrm{O}_{2}$-mediated DNA damage by a red alga (Grateloupia filicina) methanolic extract. J Sci Food Agric. 2005;85:2341-8.

Athukorala Y, Lee KW, Shahidi F, Heu MS, Kim HT, Lee JS, Jeon YJ. Antioxidant efficacy of extracts of an edible red alga (Grateloupia filicina) in linoleic acid and fish oil. J Food Lipids. 2003;10:313-27.

Carocho M, Ferreira ICFR. A review on antioxidants, prooxidants and related controversy: natural and synthetic compounds, screening and analysis methodologies and future perspectives. Food Chem Toxicol. 2013;51:15-25.

Chen S, Wu J, Chen L, Zhu C. Effects of light and temperature on the attachment and development of Gloiopeltis tenax and Gloiopeltis furcata tetraspores. J Appl Phycol. 2011;23:1045-51.

Cho E-J, Rhee S-H, Park K-Y. Antimutagenic and cancer cell growth inhibitory effects of seaweeds. Prev Nutr Food Sci. 1997;2:348-53.

Cho HB, Lee HH, Lee OH, Choi HS, Choi JS, Lee BY. Clinical and microbial evaluation of the effects on gingivitis of a mouth rinse containing an Enteromorpha linza extract. J Med Food. 2011b;14:1670-6.

Cho M, Lee HS, Kang IJ, Won MH, You S. Antioxidant properties of extract and fractions from Enteromorpha prolifera, a type of green seaweed. Food Chem. 2011a;127:999-1006.

Cho S, Kim J, Yoon M, Yang H, Um MY, Park J, Park E-J, Yoo H, Baek J, Jo J. Monitoring and optimization of the effects of the blending ratio of corn, sesame, and perilla oils on the oxidation and sensory quality of seasoned laver Pyropia spp. Fish Aquat Sci. 2015;18:27-33.

Choi EO, Kim HS, Han MH, Park C, Kim BW, Hwang JA, Choi Y, Hwang H-J. Induction of apoptosis by methyl alcohol extract of Enteromorpha linza (Linnaeus) J Agardh in U937 human leukemia cells. Trop J Pharm Res. 2014;13:881-8.

Dang HT, Lee HJ, Yoo ES, Shinde PB, Lee YM, Hong J, Kim DK, Jung JH. Antiinflammatory constituents of the red alga Gracilaria verrucosa and their synthetic analogues. J Nat Prod. 2008;71:232-40.

FAO. Fishery and aquaculture statistics. Aquaculture production 1950-2012 (Fishstat). In: FAO Fisheries and Aquaculture Department [online or CD-ROM]. Rome. Updated 2014. http:/www.fao.org/fishery/statistics/software/fishstatj/en; 2014.

Fleurence J, Levine I (eds). Seaweed in health and disease prevention. Amsterdam: Elsevier. 2016.

Go H, Hwang HJ, Nam TJ. Polysaccharides from Capsosiphon fulvescens stimulate the growth of IEC-6 cells by activating the MAPK signaling pathway. Mar Biotechnol. 2011;13:433-40.

Han AR, Kim SW, Chun SH, Nam MH, Hong CO, Kim BH, Kim TC, Lee KW. Effect of diet containing whole wheat bread with capsosiphon fulvescens and lindera obtusiloba ethanol extracts on plasma glucose and lipid levels in rats. Korean J Food Sci Technol. 2016:48:178-86,

Heo SJ, Cha SH, Lee KW, Jeon YJ. Antioxidant activities of red algae from Jeju Island. Algae. 2006;21:149-56.

Huh MK, Lee HY, Lee BK, Choi JS. Genetic diversity and relationships between wild and cultivated populations of the sea lettuce, Enteromorpha prolifera, in Korea revialed by RAPD markers. Protistology. 2004;3:243-50.

Hwang HJ, Kwon MJ, Kim IH, Nam TJ. The effect of polysaccharide extracted from the marine alga Capsosiphon fulvescens on ethanol administration. Food Chem Toxicol. 2008:46:2653-7.

Jais A, Bruning JC. Hypothalamic inflammation in obesity and metabolic disease. J Clin Invest. 2017;127:24-32.

Jin L, Abrahams JP, Skinner R, Petitou M, Pike RN, Carrell RW. The anticoagulant activation of antithrombin by heparin. Proc Natl Acad Sci. 1997;94:14683-8.

Jin Q, Dong S. Comparative studies on the allelopathic effects of two different strains of Ulva pertusa on Heterosigma akashiwo and Alexandrium tamarense. J Exp Mar Bio Ecol. 2003;293:41-55.

Kang M, Kim SW, Kim JW, Kim TH, Kim JS. Optimization of levulinic acid production from Gelidium amansii. Renew Energ. 2013;54:173-9.

Kang MC, Kang N, Kim SY, Lima IS, Ko SC, Kim YT, Kim YB, Jeung HD, Choi KS, Jeon YJ. Popular edible seaweed, Gelidium amansii prevents against dietinduced obesity. Food Chem Toxicol. 2016;90:181-7.

Kang MC, Kim SY, Kim EA, Lee JH, Kim YS, Yu SK, Chae JB, Choe IH, Cho JH, Jeon YJ. Antioxidant activity of polysaccharide purified from Acanthopanax koreanum Nakai stems in vitro and in vivo zebrafish model. Carbohydr Polym. 2015b;127:38-46.

Kang SR, Choi JH, Kim DW, Park SE, Sapkota K, Kim S, Kim SJ. A bifunctional protease from green alga Ulva pertusa with anticoagulant properties: partial purification and characterization. J Appl Phycol. 2015a;28:599-607. 
Karnjanapratum S, Tabarsa M, Cho M, You S. Characterization and immunomodulatory activities of sulfated polysaccharides from Capsosiphon fulvescens. Int J Biol Macromol. 2012;51:720-9.

Kilınc B, Koru E, Turan G, Tekogul H, Cirik S Seaweeds for food and industrial applications, 2013. INTECH Open Access Publisher. https://www.intechopen. com/books/food-industry/seaweeds-for-food-and-industrial-applications.

Kim EY, Choi YH, Lee Jl, Kim IH, Nam TJ. Antioxidant activity of oxygen evolving enhancer protein 1 purified from Capsosiphon fulvescens. J Food Sci. 2015a; 80:1412-7.

Kim EY, Nam TJ, Oh JH. Hydrophilic compartments of Capsosiphon fulvescens protein alleviate impaired spatial memory by regulating BDNF-mediated ER stress against chronic ethanol exposure. J Funct Foods. 2017;35:474-80.

Kim KN, Ahn G, Heo SJ, Kang SM, Kang MC, Yang HM, Kim D, Roh SW, Kim SK, Jeon BT, Park PJ, Jung WK, Jeon YJ. Inhibition of tumor growth in vitro and in vivo by fucoxanthin against melanoma B16F10 cells. Environ Toxicol Pharmacol. 2013a;35:39-46.

Kim KO. Re-orienting cuisine: East Asian foodways in the twenty-first century. New York: Berghahn Books. 2015.

Kim SC, Lee JR, Park SJ. Porphyra tenera induces apoptosis of oral cancer cells. Korea J Herbol. 2015b;30:25-30.

Kim YK. Total phenolic contents and antioxidant activities of Undaria pinnatifida and Capsosiphon fulvescens. Korean J Food Cook Sci. 2010;26:499-502.

Kim YM, Kim IH, Nam TJ. Capsosiphon fulvescens glycoprotein inhibits AGS gastric cancer cell proliferation by downregulating Wnt-1 signaling. Int J Oncol. 2013b;43:1395-401

Kim YM, Kim IH, Nam TJ. Inhibition of AGS human gastric cancer cell invasion and proliferation by Capsosiphon fulvescens glycoprotein. Mol Med Rep. 2013c;8:11-6.

Kundu JK, Surh YJ. Inflammation: gearing the journey to cancer. Mutat Res. 2008; 659:15-30.

Kwon HK, Kang H, Oh YH, Park SR, Kim G. Green tide development associated with submarine groundwater discharge in a coastal harbor, Jeju, Korea. Sci Rep. 2017;7:6325.

Kwon M-J, Nam T-J. A polysaccharide of the marine alga Capsosiphon fulvescens induces apoptosis in AGS gastric cancer cells via an IGF-IR-mediated PI3K/Akt pathway. Cell Biol Int. 2007:31:768-75.

Lee JH, Han KD, Jung HM, Youn YH, Lee JY, Park YG, Lee S-H, Park YM. Association between obesity, abdominal obesity, and adiposity and the prevalence of atopic dermatitis in young Korean adults: the Korea National Health and Nutrition Examination Survey 2008-2010. Allergy Asthma Immunol Res. 2016a;8:107-14.

Lee JH, Kim HH, Ko JY, Jang JH, Kim GH, Lee JS, Nah JW, Jeon YJ. Rapid preparation of functional polysaccharides from Pyropia yezoensis by microwave-assistant rapid enzyme digest system. Carbohydr Polym. 2016b;153:512-7.

Lee SA, Moon SM, Choi YH, Han SH, Park BR, Choi MS, Kim JS, Kim YH, Kim DK, Kim CS. Aqueous extract of Codium fragile suppressed inflammatory responses in lipopolysaccharide-stimulated RAW264.7 cells and carrageenaninduced rats. Biomed Pharmacother. 2017;93:1055-64.

Leung MYM, Carlsson NP, Colditz GA, Chang S-H. The burden of obesity on diabetes in the United States: medical expenditure panel survey, 2008 to 2012. Value Health. 2017;20:77-84.

Mabeau S, Fleurence J. Seaweed in food products: biochemical and nutritional aspects. Trends Food Sci Technol. 1993;4:103-7.

Maeda R, Ida T, Ihara H, Sakamoto T. Immunostimulatory activity of polysaccharides isolated from Caulerpa lentillifera on macrophage cells. Biosci Biotechnol Biochem. 2012a;76:501-5.

Maeda R, Ida T, Ihara H, Sakamoto T. Induction of apoptosis in MCF-7 cells by beta-1,3-xylooligosaccharides prepared from Caulerpa lentillifera. Biosci Biotechnol Biochem. 2012b;76:1032-4.

Manzoor Z, Koo J-E, Ali I, Kim J-E, Byeon S-H, Yoo E-S, Kang H-K, Hyun J-W, Lee $\mathrm{N}$-H, Koh Y-S. 4-Hydroxy-2, 3-dimethyl-2-nonen-4-olide has an inhibitory effect on pro-inflammatory cytokine production in CpG-stimulated bone marrow-derived dendritic cells. Mar drugs. 2016;14:88.

Matanjun P, Mohamed S, Mustapha NM, Muhammad K. Nutrient content of tropical edible seaweeds, Eucheuma cottonii, Caulerpa lentillifera and Sargassum polycystum. J Appl Phycol. 2009;21:75-80.

Meinita MDN, Marhaeni B, Hong Y-K, Jeong G-T. Enzymatic saccharification of agar waste from Gracilaria verrucosa and Gelidium latifolium for bioethanol production. J Appl Phycol. 2017;29:3201-9.

Meinita MDN, Marhaeni B, Winanto T, Jeong G-T, Khan MNA, Hong Y-K Comparison of agarophytes (Gelidium, Gracilaria, and Gracilariopsis) as potential resources for bioethanol production. J Appl Phycol. 2013;25:195761.

Mohibbullah M, Abdul Hannan M, Park IS, Moon IS, Hong YK. The edible red seaweed Gracilariopsis chorda promotes axodendritic architectural complexity in hippocampal neurons. J Med Food. 2016;19:638-44.

Mohibbullah M, Hannan MA, Choi JY, Bhuiyan MM, Hong YK, Choi JS, Choi IS, Moon IS. The edible marine alga Gracilariopsis chorda alleviates hypoxia/ reoxygenation-induced oxidative stress in cultured hippocampal neurons. J Med Food. 2015;18:960-71.

Nguyen TH, Ra CH, Sunwoo I, Jeong GT, Kim SK. Bioethanol production from Gracilaria verrucosa using Saccharomyces cerevisiae adapted to $\mathrm{NaCl}$ or galactose. Bioprocess Biosyst Eng. 2017;40:529-36.

Nguyen VT, Ueng JP, Tsai GJ. Proximate composition, total phenolic content, and antioxidant activity of seagrape (Caulerpa lentillifera). J Food Sci. 2011;76:950-8

Oh KH, Choi Y-S. Development of a pasting and garnishing machine for manufacturing kimbugak. J Biosyst Eng. 2015;40:320-6.

Park $\mathrm{MH}$. The effect of Capsosiphon fulvecense extract on inhibition of platelet aggregation and serum lipid level in ovariertomized rats. J Life Sci. 2005;15:1028-33.

Park NH, Choi JS, Hwang SY, Kim YC, Hong YK, Cho KK, Choi IS. Antimicrobial activities of stearidonic and gamma-linolenic acids from the green seaweed Enteromorpha linza against several oral pathogenic bacteria. Bot Stud. 2013;54:39.

Park SY, Song H-H, Ha S-D. Synergistic effects of $\mathrm{NaOCl}$ and ultrasound combination on the reduction of Escherichia coli and Bacillus cereus in raw laver. Foodborne Pathog Dis. 2014;11:373-8.

Patra JK, Baek KH. Antibacterial activity and action mechanism of the essential oil from Enteromorpha linza L. against foodborne pathogenic bacteria. Molecules. 2016;21:388.

Patra JK, Das G, Baek KH. Antibacterial mechanism of the action of Enteromorpha linza L. essential oil against Escherichia coli and salmonella typhimurium. Bot Stud. 2015;56:13.

Pesic M, Greten FR. Inflammation and cancer: tissue regeneration gone awry. Curr Opin Cell Biol. 2016;43:55-61.

Pushpamali WA, Nikapitiya C, Zoysa MD, Whang I, Kim SJ, Lee J. Isolation and purification of an anticoagulant from fermented red seaweed Lomentaria catenata. Carbohydr Polym. 2008;73:274-9.

Qi H, Sun Y. Antioxidant activity of high sulfate content derivative of ulvan in hyperlipidemic rats. Int J Biol Macromol. 2015;76:326-9.

Qi H, Zhang Q, Zhao T, Hu R, Zhang K, Li Z. In vitro antioxidant activity of acetylated and benzoylated derivatives of polysaccharide extracted from Ulva pertusa (Chlorophyta). Bioorganic Med Chem Lett. 2006;16:2441-5.

Qi X, Mao W, Chen Y, Chen Y, Zhao C, Li N, Wang C. Chemical characteristics and anticoagulant activities of two sulfated polysaccharides from Enteromorpha linza (Chlorophyta). J Ocean U China. 2013;12:175-82.

Sanjeewa KKA, Lee JS, Kim WS, Jeon YJ. The potential of brown-algae polysaccharides for the development of anticancer agents: an update on anticancer effects reported for fucoidan and laminaran. Carbohydr Polym. 2017;177:451-9.

Seo MJ, Lee OH, Choi HS, Lee BY. Extract from edible red seaweed (Gelidium amansii) inhibits lipid accumulation and ROS production during differentiation in 3T3-L1 cells. Prev Nutr Food Sci. 2012;17:129-35.

Shao LL, XU J, Shi MJ, Wang XL, Li YT, Kong LM, Hider RC, Zhou T. Preparation, antioxidant and antimicrobial evaluation of hydroxamated degraded polysaccharides from Enteromorpha prolifera. Food Chem. 2017;237:481-7.

Sharma BR, Kim HJ, Rhyu DY. Caulerpa lentillifera extract ameliorates insulin resistance and regulates glucose metabolism in C57BL/KsJ-db/db mice via PI3K/AKT signaling pathway in myocytes. J Transl Med. 2015;13:62.

Sharma BR, Rhyu DY. Anti-diabetic effects of Caulerpa lentillifera: stimulation of insulin secretion in pancreatic beta-cells and enhancement of glucose uptake in adipocytes. Asian Pac J Trop Biomed. 2014;4:575-80.

Shaw NS, Liu YH. Bioavailability of iron from purple laver (Porphyra spp.) estimated in a rat hemoglobin regeneration bioassay. J Agric Food Chem. 2000;48:1734-7.

Shi MJ, Wei X, Xu J, Chen BJ, Zhao DY, Cui S, Zhou T. Carboxymethylated degraded polysaccharides from Enteromorpha prolifera: preparation and in vitro antioxidant activity. Food Chem. 2017;215:76-83.

Song SJ, Ryu J, Khim JS, Kim W, Yun SG. Seasonal variability of community structure and breeding activity in marine phytal harpacticoid copepods on Ulva pertusa from Pohang, east coast of Korea. J Sea Res. 2010;63:1-10. 
Synytsya A, Choi DJ, Pohl R, Na YS, Capek P, Lattova E, Taubner T, Choi JW, Lee CW, Park JK, Kim WJ, Kim SM, Lee J, Park YI. Structural features and anticoagulant activity of the sulphated polysaccharide SPS-CF from a green alga Capsosiphon fulvescens. Mar Biotechnol (NY). 2015;17:718-35.

Tang Z, Gao H, Wang S, Wen S, Qin S. Hypolipidemic and antioxidant properties of a polysaccharide fraction from Enteromorpha prolifera. Int J Biol Macromol. 2013;58:186-9.

Walenga JM, Bick RL. Heparin-induced thrombocytopenia, paradoxical thromboembolism, and other side effects of heparin therapy. Med Clin North Am. 1998;82:635-58.

Wang X, Zhang Z, Yao Q, Zhao M, Qi H. Phosphorylation of low-molecularweight polysaccharide from Enteromorpha linza with antioxidant activity. Carbohydr Polym. 2013a;96:371-5.

Wang X, Zhang Z, Yao Z, Zhao M, Qi H. Sulfation, anticoagulant and antioxidant activities of polysaccharide from green algae Enteromorpha linza. Int J Biol Macromol. 2013b;58:225-30.

Wi SG, Kim HJ, Mahadevan SA, Yang DJ, Bae HJ. The potential value of the seaweed Ceylon moss (Gelidium amansii) as an alternative bioenergy resource. Bioresour Technol. 2009;100:6658-60.

Woo MS, Choi HS, Lee OH, Lee BY. The edible red alga, Gracilaria verrucosa, inhibits lipid accumulation and ROS production, but improves glucose uptake in 3T3-L1 cells. Phytother Res. 2013;27:1102-5.

Xu J, Xu LL, Zhou QW, Hao SX, Zhou T, Xie HJ. Isolation, purification, and antioxidant activities of degraded polysaccharides from Enteromorpha prolifera. Int J Biol Macromol. 2015;81:1026-30.

Yang H, Jung K, Gang K, Song B, Lim H, Na H, Mun H, Heo N. Physicochemical composition of seaweed fulvescens (Capsosiphon fulvescens). Korean J Food Sci Technol. 2005;37:912-7.

Yang TH, Yao HT, Chiang MT. Red algae (Gelidium amansii) hot-water extract ameliorates lipid metabolism in hamsters fed a high-fat diet. J Food Drug Anal. 2017:25:931-8

Zhang LX, Zhang N, Li J, Wang Z. (2013). New a-glucosidase inhibitory polysaccharides isolated from marine green algae Enteromorpha Linza. Advanced materials research, Trans Tech Publ 2013a;634:1010-1015.

Zhang Z, Wang X, Li J, Liu C, Zhang Q. Inhibitory effects of Enteromorpha linza polysaccharide on micronucleus of Allium sativum root cells. Int J Biol Macromol. 2016;87:252-5.

Zhang Z, Wang X, Yu S, Yin L, Zhao M, Han Z. Synthesized oversulfated and acetylated derivatives of polysaccharide extracted from Enteromorpha linza and their potential antioxidant activity. Int J Biol Macromol. 2011;49:1012-5.

Zhang Z, Wang X, Zhao M, Qi H. O-acetylation of low-molecular-weight polysaccharide from Enteromorpha linza with antioxidant activity. Int J Biol Macromol. 2014;69:39-45.

Zhang Z, Wang X, Zhao M, Yu S, Qi H. The immunological and antioxidant activities of polysaccharides extracted from Enteromorpha linza. Int J Biol Macromol. 2013b;57:45-9.

Zheng J, Chen Y, Yao F, Chen W, Shi G. Chemical composition and antioxidant/ antimicrobial activities in supercritical carbon dioxide fluid extract of Gloiopeltis tenax. Mar Drugs. 2012;10:2634-47.

\section{Ready to submit your research? Choose BMC and benefit from:}

- fast, convenient online submission

- thorough peer review by experienced researchers in your field

- rapid publication on acceptance

- support for research data, including large and complex data types

- gold Open Access which fosters wider collaboration and increased citations

- maximum visibility for your research: over $100 \mathrm{M}$ website views per year

At BMC, research is always in progress.

Learn more biomedcentral.com/submissions 